\title{
Intensive Linear Pedestrian Survey of Callaghan Road Between Ingram and Bandera Roads and Along Zarzamora Creek, San Antonio, Bexar County, Texas
}

Jennifer L. Thompson

Follow this and additional works at: https://scholarworks.sfasu.edu/ita

Part of the American Material Culture Commons, Archaeological Anthropology Commons, Environmental Studies Commons, Other American Studies Commons, Other Arts and Humanities Commons, Other History of Art, Architecture, and Archaeology Commons, and the United States History Commons

Tell us how this article helped you.

This Article is brought to you for free and open access by the Center for Regional Heritage Research at SFA ScholarWorks. It has been accepted for inclusion in Index of Texas Archaeology: Open Access Gray Literature from the Lone Star State by an authorized editor of SFA ScholarWorks. For more information, please contact cdsscholarworks@sfasu.edu. 


\section{Intensive Linear Pedestrian Survey of Callaghan Road Between Ingram and Bandera Roads and Along Zarzamora Creek, San Antonio, Bexar County, Texas}

\section{Licensing Statement}

This is a work produced for the Texas Department of Transportation (TxDOT) by the report producer. TxDOT and the report producer jointly own all rights, title, and interest in and to all intellectual property developed under TXDOT's contract with the report producer. The report may be cited and brief passages from this publication may be reproduced without permission provided that credit is given to both TXDOT and the report producer. Permission to reprint an entire chapter, section, figures or tables must be obtained in advance from either the Supervisor of the Archeological Studies Branch, Environmental Affairs Division, Texas Department of Transportation, 125 East 11th Street, Austin, Texas, 78701 or from the report producer. 


\title{
Intensive Linear Pedestrian Survey of Callaghan ROAD BETWEeN INGRAM AND BANDERA ROADS and Along Zarzamora Creek, San Antonio, Bexar County, Texas
}

\author{
BY \\ JENNIFER L. THOMPSON
}

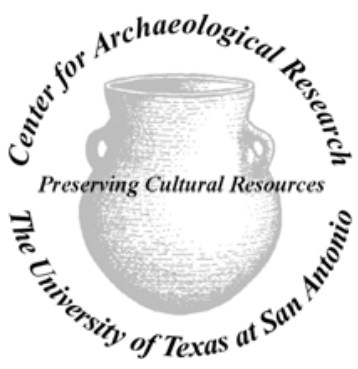

Archaeological Report, No. 372

Center for Archaeological Research

The University of Texas at San Antonio (C) 2007 


\title{
Intensive Linear Pedestrian Survey of Callaghan Road between Ingram and Bandera Roads and Along Zarzamora Creek, San Antonio, Bexar County, Texas
}

\author{
by \\ Jennifer L. Thompson
}

Steve A. Tomka

Principal Investigator

Texas Antiquities Permit No. 4320

CSJ\#s 0915-12-154 and 0915-12-266

Prepared for

HNTB Corporation

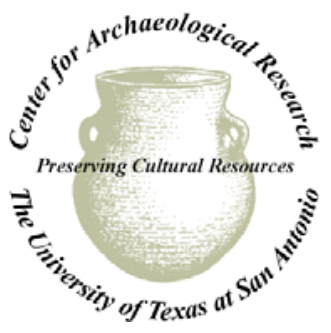

Prepared by

Center for Archaeological Research

The University of Texas at San Antonio

Archaeological Report, No. 372

(C)2007 
A list of publications offered by the Center for Archaeological Research is available. Call (210) 458-4378; write to the Center for Archaeological Research, The University of Texas at San Antonio, One UTSA Circle, San Antonio, Texas 78249-1644; e-mail to car@utsa.edu; or visit CAR's web site at http://car.utsa.edu. 


\section{Abstract}

November 15 and 16, 2006, The Center for Archaeological Research at The University of Texas at San Antonio conducted an intensive survey of 3.5 miles of Callaghan Road between Ingram and Bandera Roads and along Zarzamora Creek in San Antonio, Bexar County, Texas. The City of San Antonio is planning to widen this section of Callaghan Road and to re-channelize Zarzamora Creek north of Callaghan Road to alleviate flooding in the area. The intensive linear survey was conducted under the Texas Antiquities Permit No. 4320 with Steve A. Tomka serving as Principal Investigator and Jennifer L Thompson as Project Archeologist. This project serves to satisfy the requirements of Section 106 of the National Historic Preservation Act.

The project area is in urban west San Antonio and crosses both residential and commercial zones. Buried utilities along Callaghan Road and Zarzamora Creek cross the entire length of the project area. Sections of new right-of-way (ROW) that are relatively undeveloped were selected for shovel testing while both side of Zarzamora Creek were examined by backhoe trenches and shovel tests in efforts to find deeply buried cultural deposits. Other sections of the roadway are paved making subsurface examination difficult. Because of the level of development, CAR targeted approximately .35 miles of the 1.5 new ROW along Callaghan Road. At Zarzamora Creek, wetland mitigation and efforts to reduce flooding will impact 2.31 acres. CAR excavated backhoe trenches and shovel tests in portions of this area most suitable for excavation, away from construction dumps, buried utility lines, fences, etc.

While some cultural material were found in one shovel test and in two backhoe trenches in the area of Zarzamora Creek, the artifacts were not in primary context or associated with other artifacts. Fire-cracked rock lay in association with modern plastic and construction material in one shovel test and with alluvial deposits above creek channel gravels in one backhoe trench.

Because the APE has seen so much development and the limited cultural material recovered were in questionable context, CAR recommends that the planned construction project proceed. No artifacts were collected during this survey. All notes and project related materials are curated at the Center for Archaeological Research according to Texas Historical Commission guidelines. 


\section{Table of Contents}

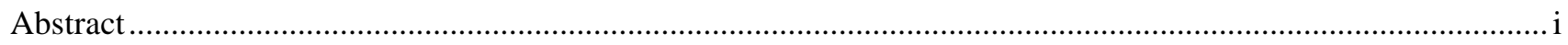

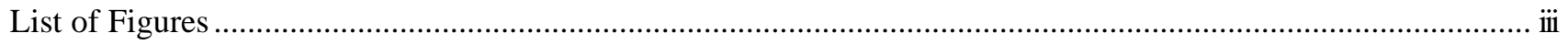

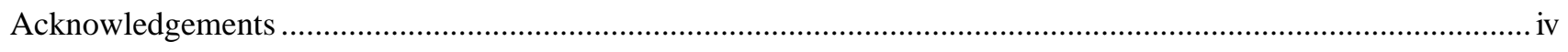

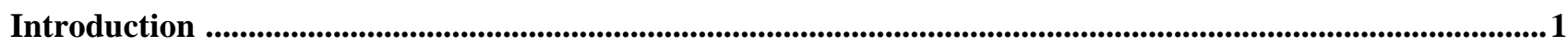

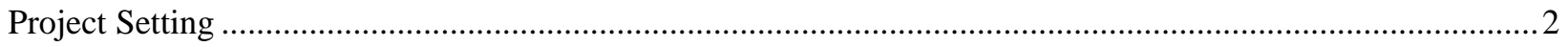

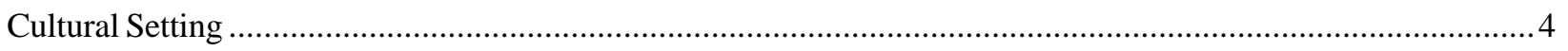

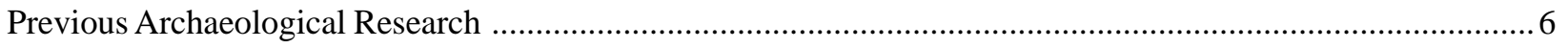

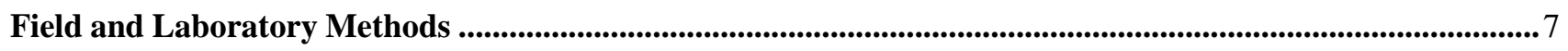

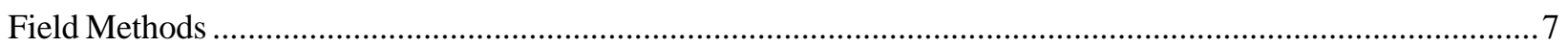

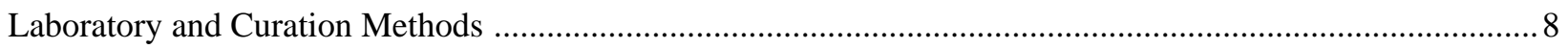

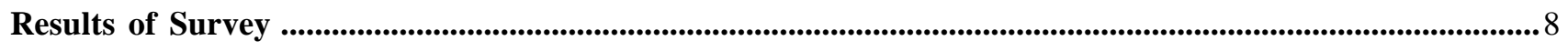

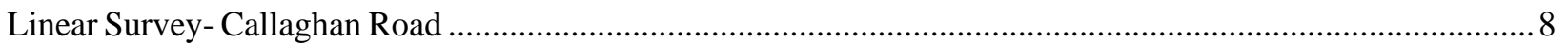

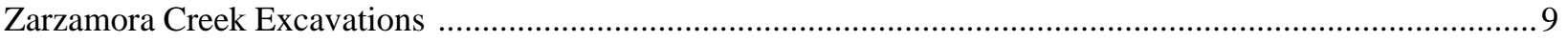

Conclusions and Recommendations .............................................................................................................. 14

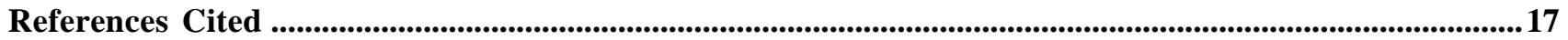




\section{List of Figures}

Figure 1. The APE is highlighted on the 1993 San Antonio, West, Texas USGS topographic quadrangle.

Figure 2. Between Ingram and Oak Knoll, Callaghan Road is commercially developed and retains little potential for encountering intact cultural or buried deposits.

Figure 3. Sections between Horseshoe Bend East and Oak Knoll have mixed commercial and residential development with more areas available for shovel testing and therefore a greater chance of encountering intact archaeological deposits exists.

Figure 4. The eastern end of the APE between Horseshoe Bend East and Bandera Roads has also seen commercial development and retains little potential for encountering intact archaeological deposits due to the amount of paved ground surface.

Figure 5. The APE includes areas east of the current location of Zarzamora Creek, encompassing 2.31 acres of floodplain and flood terrace that have the greatest potential for containing archeological deposits......................... 5

Figure 6. South of Callaghan Road the creek has already been modified from its natural channel. .................................... 5

Figure 7. 2006 aerial photograph showing sections along Callaghan proposed for subsurface testing. ........................... 7

Figure 8. 2006 aerial photograph showing locations of the channel limits as staked by Pape Dawson, Inc. and the

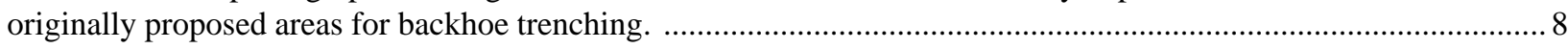

Figure 9. 2006 aerial showing locations of shovel tests along Callaghan Road. ........................................................ 9

Figure 10. Aerial photograph showing the estimated location of construction dump south of Callaghan between Zarzamora Creek and Horseshoe Bend East.

Figure 11. The eastern edge of the lot east of Zarzamora Creek south of Callaghan is paved and the entire lot is littered with construction debris.

Figure 12. Aerial photograph showing the placement of backhoe trenches and shovel tests near Zarzamora Creek. ......... 11

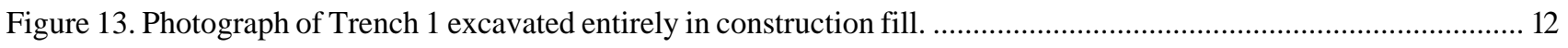

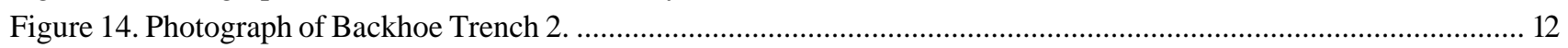

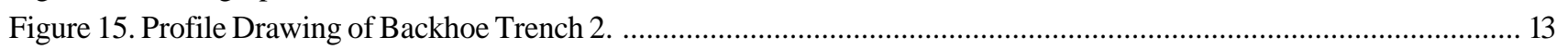

Figure 16. Photograph of Backhoe Trench 3 showing 1.25 meters of silty clay........................................................... 15

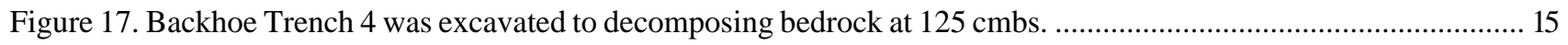

Figure 18. Culverts were stacked to allow floodwaters to drain while also serving to keep horses out of the creek, according to a former horse caretaker on the property. 


\section{Acknowledgments}

The author would like to thank those who participated in the successful completion of this project. Steve Dean of Pape-Dawson Engineers Incorporated was responsible for marking the proposed APE and explaining the extent of construction impact at Zarzamora Creek. Heartfelt thanks to Carl "Gator" Krueger of CESA Contractors who excavated backhoe trenches for CAR. Leonard Kemp, Lindy Martinez, and Joe Thompson performed the field excavations. They worked hard to complete the work ahead of schedule in a disturbed setting that often involved difficult excavation through construction materials and rocky soils. Leonard Kemp also served as the GIS specialist collecting data and creating images used in this report. I would also like to thank Bruce Moses for drafting the report figures and Claudia Branton for editing the final version of the report. 


\section{Introduction}

The HNTB Corporation of San Antonio contracted the Center for Archaeological Research (CAR) at The University of Texas at San Antonio to perform an intensive pedestrian survey along 1.5 miles of Callaghan Road between Ingram and Bandera Roads and to examine three areas along portions of Zarzamora Creek north of Callaghan Road in San Antonio, Bexar County, Texas. This archaeological fieldwork fulfills the requirements of Section 106 of the National Historic Preservation Act in November 2006. The City of San Antonio owns the property under investigation.
The Area of Potential Effect (APE) as described to CAR by HNTB is depicted on the 1993 edition of the San Antonio West, Texas 7.5-minute United States Geological Survey (USGS) topographic quadrangle map (Figure 1). The City of San Antonio plans to add new ROW intermittently to 1.5 miles of Callaghan Road between Ingram and Bandera Roads expanding the existing ROW an additional 1 to $5 \mathrm{~m}$. This primarily concerns the east/south side of Callaghan Road, although plans also show intermittent improvements along the west/north side as well. Construction plans also

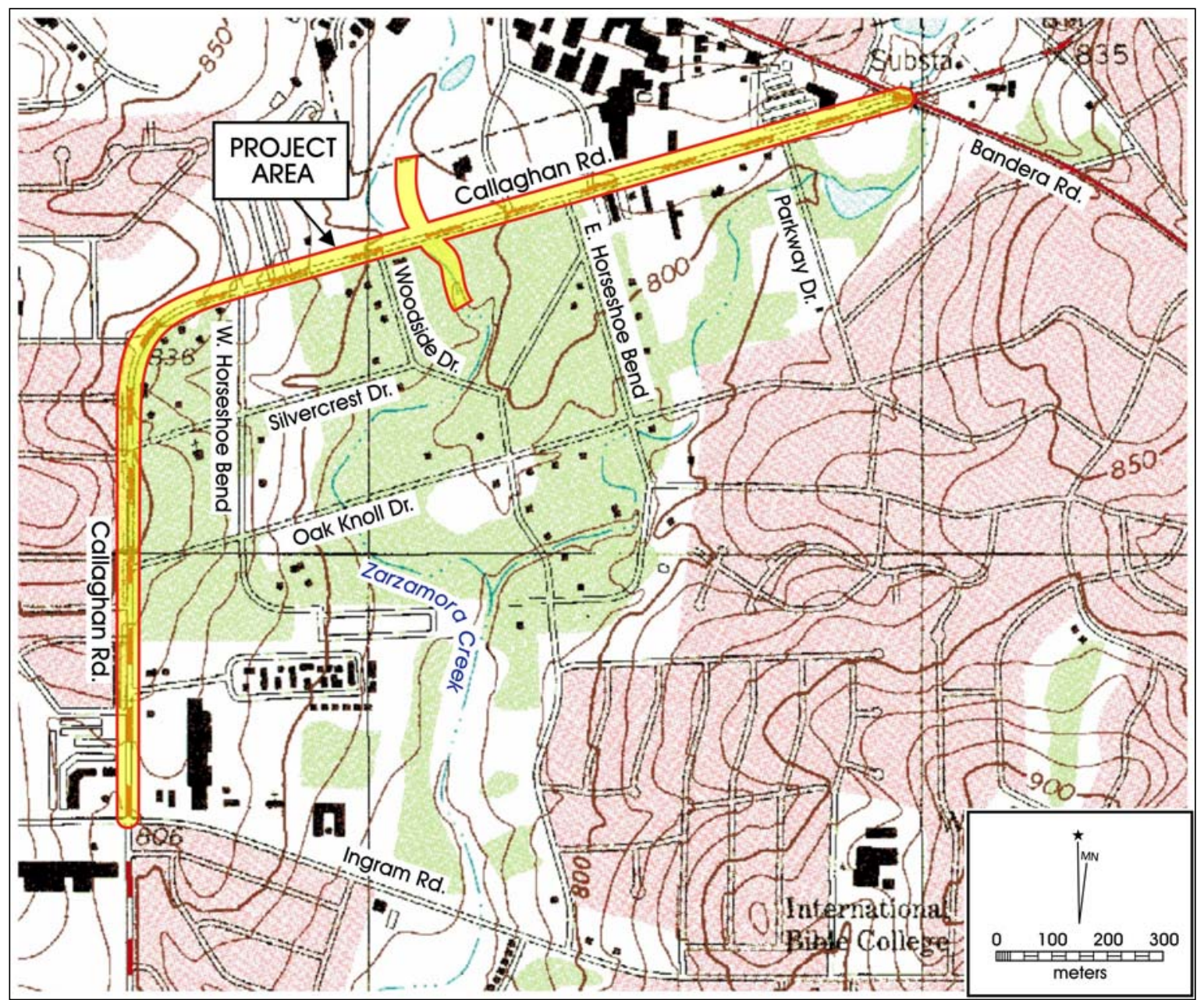

Figure 1. The APE is highlighted on the 1993 San Antonio, West, Texas USGS topographic quadrangle. 
show extension of an access road between Rainmaker Road and White Cloud measuring $17 \mathrm{~m}$ wide from the existing ROW. The current ROW varies from Ingram to Bandera Roads but is approximately $22 \mathrm{~m}$ wide in places.

In addition, HNTB Corporation construction plans show channelization impacts to portions along Zarzamora Creek located on both sides of the Callaghan Road. As described in the Scope of Work, six areas up to $130 \mathrm{~m}$ from the existing ROW were to be targeted for construction on the north side of Callaghan Road. Excavations of two triangular areas on the east- and west-descending banks of the creek reach a depth of 4-5 $\mathrm{m}$ (13-16 ft) below surface. These two areas account for a combined .83 acres, although only 35-40 percent of these areas are actually outside of the active channel. Two smaller rectangular areas located immediately south of the first two areas equal .25 acres of combined creek bank. The projected impacts in these two areas will occur from down cutting to sculpt the banks while increasing channel carrying capacity.

In addition, construction will impact a rectangular area found on the south side of Callaghan Road, though this area has been previously disturbed. The project would add approx 0.11 acres of variable width easement to the existing variable width easement on Zarzamora Creek. Dredging and re-channelization of the creek should be no greater than $16 \mathrm{ft}$.

HNTB asked Pape-Dawson Engineers Incorporated to survey and mark the six areas and ROW along Zarzamora Creek and Callaghan Road. These efforts were to help CAR personnel determine the exact locations of the specific areas of impact, most importantly along Zarzamora Creek. The staked area was much larger than expected based on previous plans given to CAR and described above. After consulting with Pape-Dawson at the request of HNTB, CAR learned that the APE is much larger than originally described to CAR and impacts to the APE are different from any descriptions CAR received. Pape-Dawson Engineers staked an area approximately $9365 \mathrm{~m}^{2}$ (2.31 acres) encompassing land adjacent to Zarzamora Creek. They also explained that plans for the area include channelization of Zarzamora Creek in addition to excavations up to $15 \mathrm{ft}$. for wetland reconstruction to satisfy other environmental regulations regarding wetlands impacted by the construction project. This increases the acreage of the APE at Zarzamora Creek to 2.31 acres.

\section{Project Setting}

Callaghan Road is a narrow, two-lane thoroughfare accessing neighborhoods, schools, and businesses in west San Antonio near Leon Valley. Most lots along this section have businesses with parking lots though some remain vacant. City utilities (water, sewer, electric, gas) lay buried across the entire Callaghan ROW and along Zarzamora Creek. The western portion of the APE, between Ingram Road and Oak Knoll Drive, crosses extensive commercial developments and retains little potential for encountering intact cultural or buried deposits (Figure 2). Most of these businesses have paved parking lots that limit our use of typical archeological survey methods. Sections between Horseshoe Bend East and Oak Knoll Drive have mixed commercial and residential development with more areas available for shovel testing and therefore a greater chance of encountering intact archaeological deposits exists. This section is where the proposed ROW reaches its narrowest (Figure 3). The eastern end of the APE, between Horseshoe Bend East and Bandera Road, has also seen commercial development and retains little potential for encountering intact archaeological deposits due to the amount of paved ground surface (Figure 4). Zarzamora Creek crosses Callaghan Road between Horseshoe Bend East and Woodside Drive. North of Callaghan, the creek is narrow, meandering out of the project area to the northwest. The APE includes areas east of the location of the creek as depicted on 2006 USGS topographic maps, encompassing .2.31 acres of floodplain and flood terrace that have the greatest potential for containing archeological deposits. Live oak and Retama trees stand throughout this area (Figure 5). South of Callaghan Road the creek was modified from its natural channel prior to this study (Figure 6).

The proposed project area is depicted on Sheet 43 of the Soil Survey of Bexar County, Texas (Taylor et al. 1991). The proposed linear project area traverses several soils. The majority of the project area consists of the Brackett-Austin complex (BsC), 1 to 5 percent slopes. Houston Black gravelly clays (HuB), 1 to 3 percent slopes comprise the second largest area of soils. Lewisville silty clays (LvA) occur near the center of the proposed project area as a narrow band flanking the right descending bank-line of Zarzamora Creek. Trinity and Frio soils (Tf), frequently flooded, form the channels of Zarzamora Creek and an unnamed tributary near the northern terminus of the proposed project area. At the southern terminus, a narrow band of Austin silty clay ( $\mathrm{AuB}$ ) 


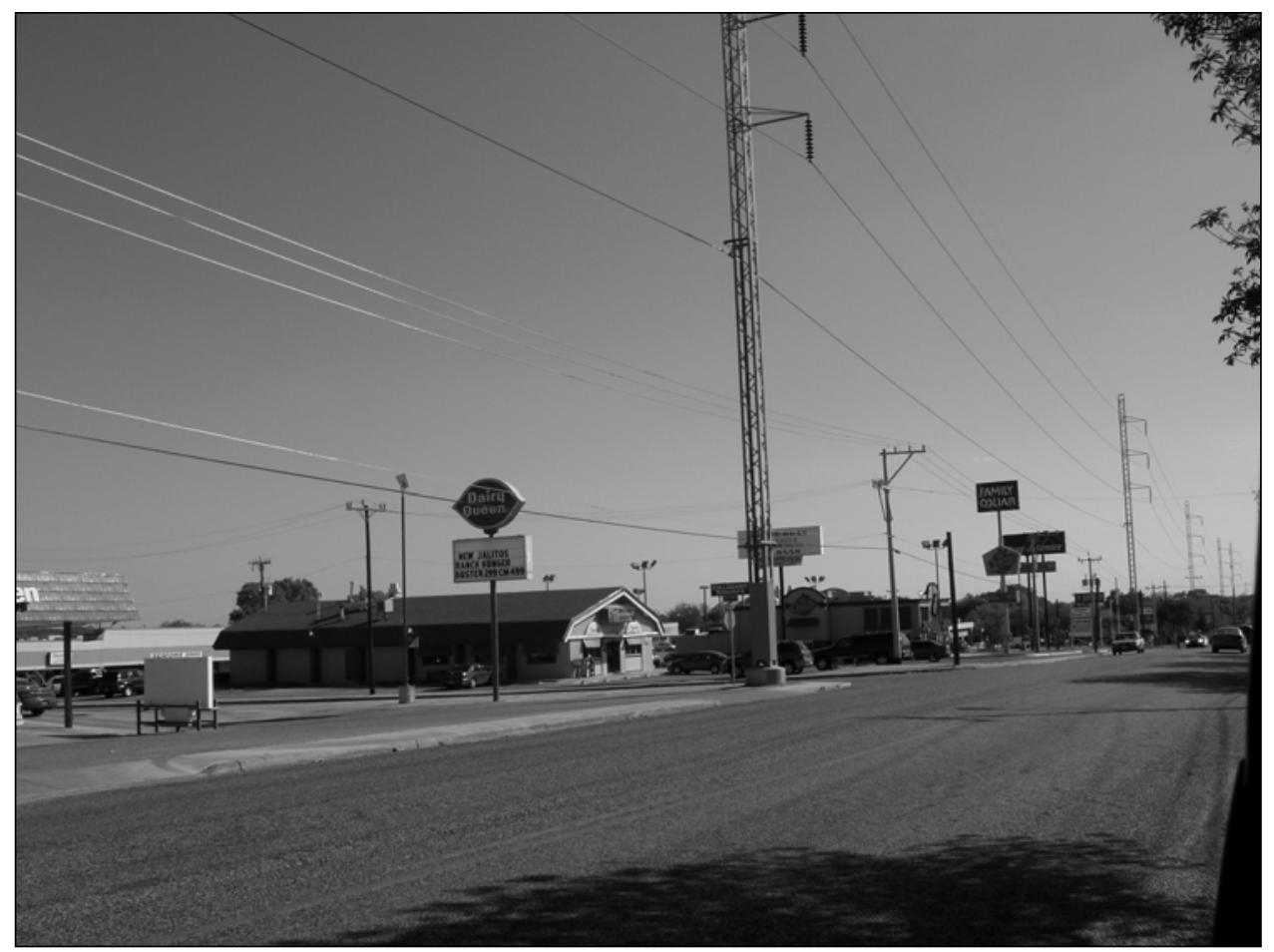

Figure 2. Between Ingram and Oak Knoll, Callaghan Road is commercially developed and retains little potential for encountering intact cultural or buried deposits.

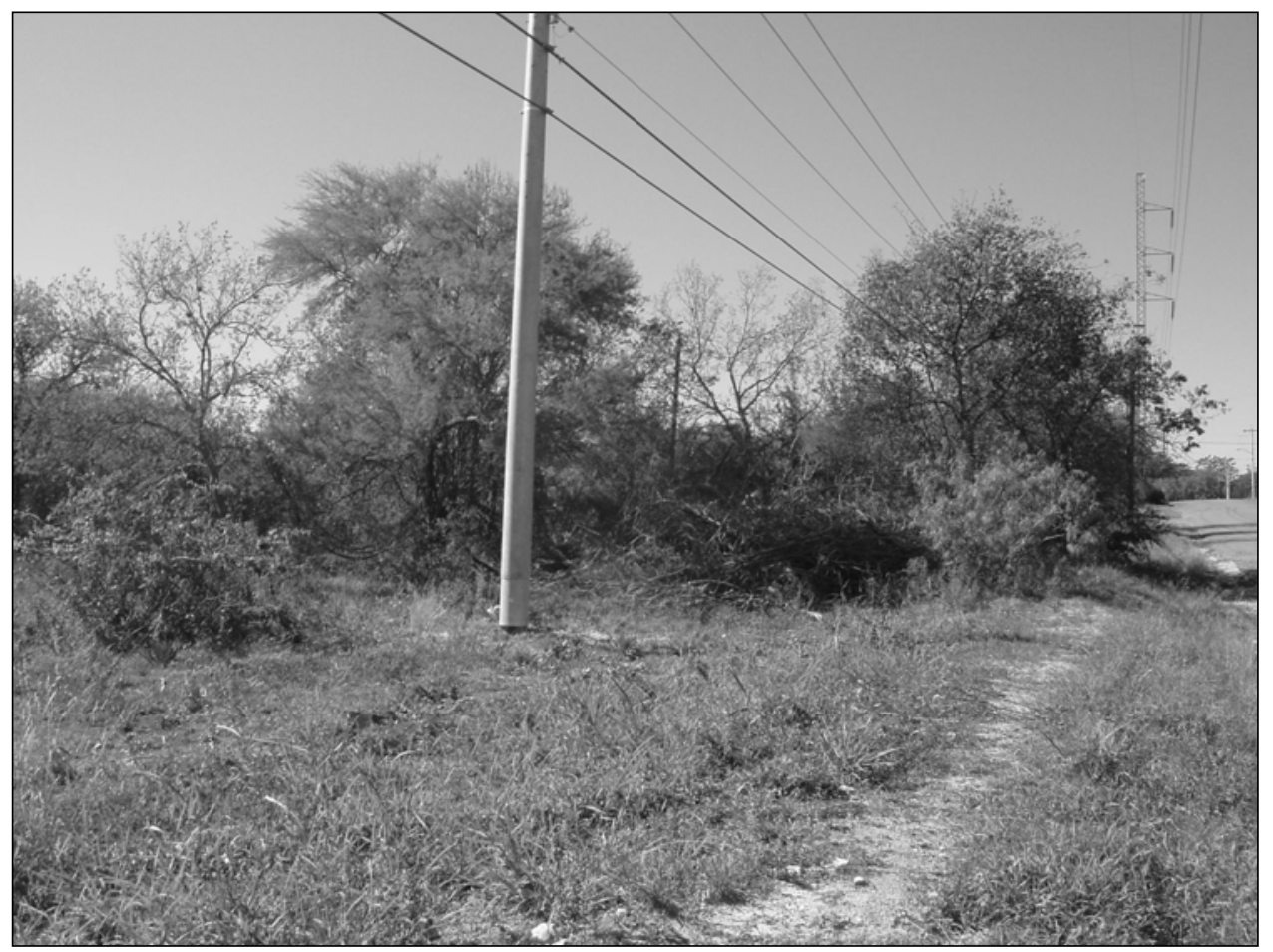

Figure 3. Sections between Horseshoe Bend East and Oak Knoll have mixed commercial and residential development with more areas available for shovel testing and therefore a greater chance of encountering intact archaeological deposits exists. 


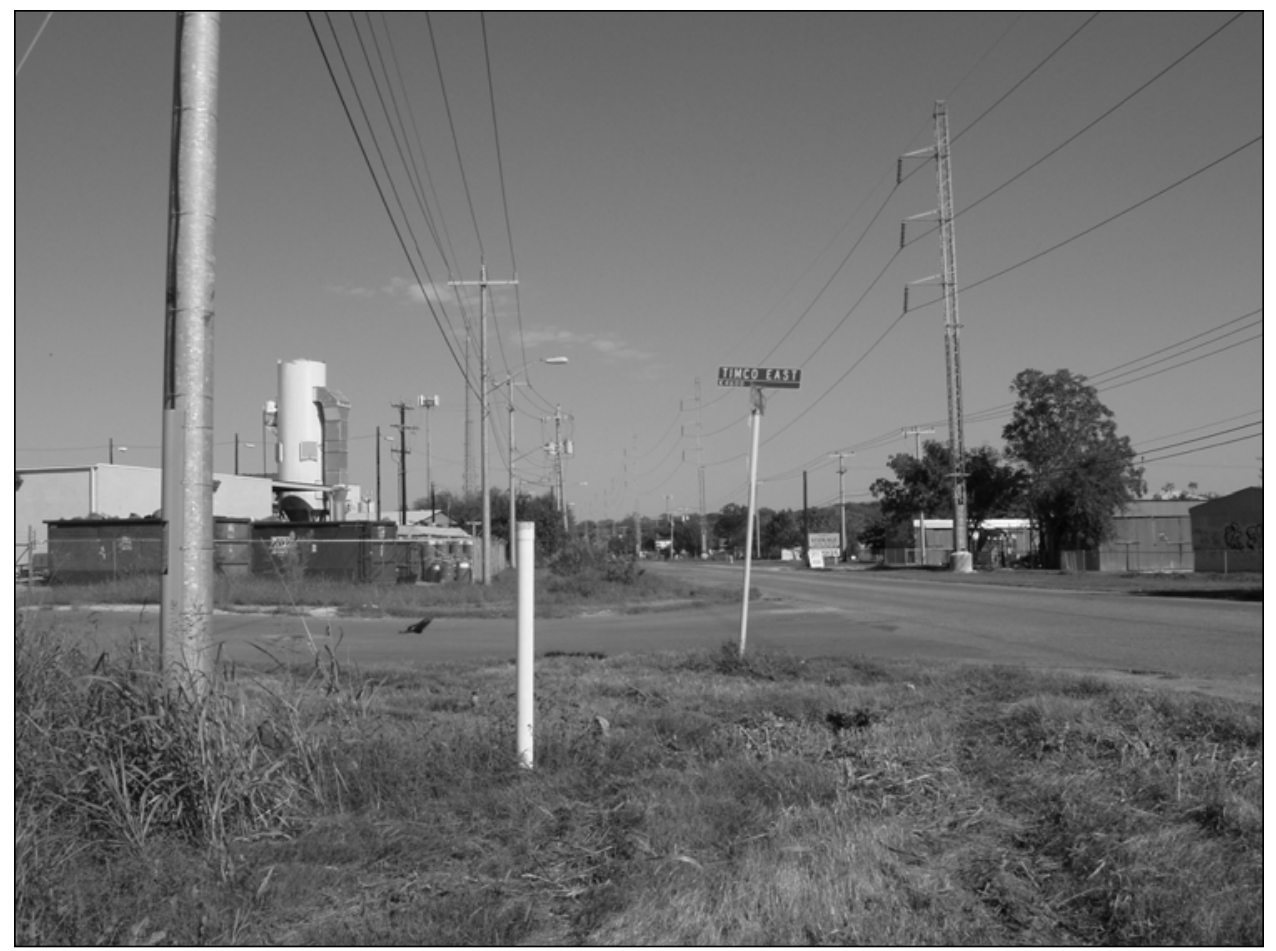

Figure 4. The eastern end of the APE between Horseshoe Bend East and Bandera Roads has also seen commercial development and retains little potential for encountering intact archaeological deposits due to the amount of paved ground surface.

forms the channel of another unnamed tributary of Zarzamora Creek. With regard to the Trinity and Frio soils, significant prehistoric archaeological sites have been recorded within this soil type along streams in Bexar County.

\section{Cultural Setting}

A review of the Texas Archeological Sites Atlas (THC 2006) indicates that there are no previously recorded prehistoric or historic archaeological sites within the proposed APE. The nearest prehistoric site to the proposed project area is 41BX46, a Middle Archaic open campsite roughly $1.5 \mathrm{~km}$ due north. The nearest historic site is the Barnes-Laird House, an early twentieth century National Register of Historic Places property, located about $3 \mathrm{~km}$ southeast of the project area in the Monte Vista Historic District. The currently proposed development will not impact either of these previously recorded sites.

CAR consulted numerous historic maps of the general vicinity for evidence of historic period settlement in the proposed project area. Examination of the 1903 USGS San Antonio quadrangle map shows no structures within the proposed project area; Callaghan Road had not yet extended south of Bandera Road in 1903. The nearest structure on the 1903 USGS map occurs roughly $2 \mathrm{~km}$ east of the northern terminus of the proposed project area. The 1922 Corps of Engineers Lytle quadrangle map depicts Callaghan Road connecting Bandera and Ingram Roads, but no structures existed within the proposed project area at that time. The nearest structure, the Oppenheimer Farm, on the 1922 map sits about $1 \mathrm{~km}$ southwest of the southern terminus of the proposed project area. In reference to the 1942 Corps of Engineers West San Antonio quadrangle, the first structure appears along the proposed project area, at the northeast corner of the Callaghan and Ingram Roads intersection. The 1953 USGS San Antonio West quadrangle depicts at least seven structures along the east side of Callaghan Road, with two structures between Parkway and East Horseshoe Bend Drives, four structures between West Horseshoe Bend and Silvercrest Drive, and one structure between Flynn Lane and Ingram Road. Little change from the 1953 map is apparent on the 1967 USGS San Antonio 


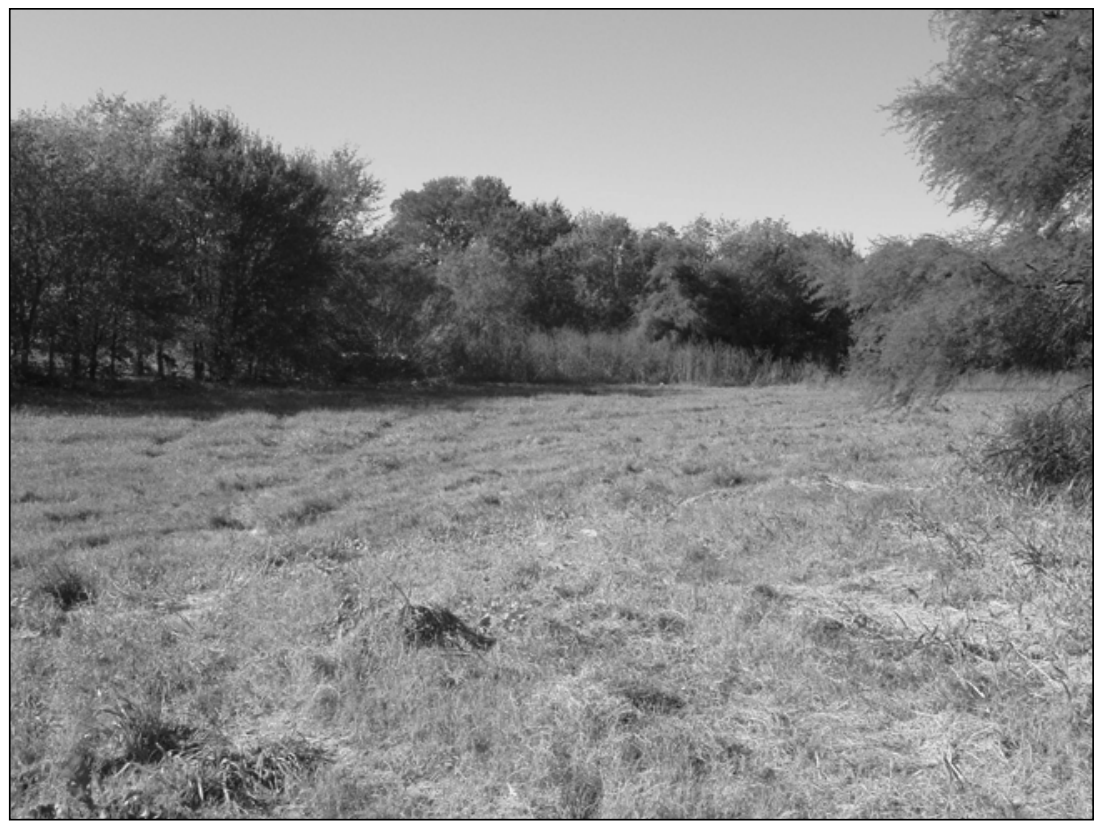

Figure 5. The APE includes areas east of the current location of Zarzamora Creek, encompassing 2.31 acres of floodplain and flood terrace that have the greatest potential for containing archeological deposits.

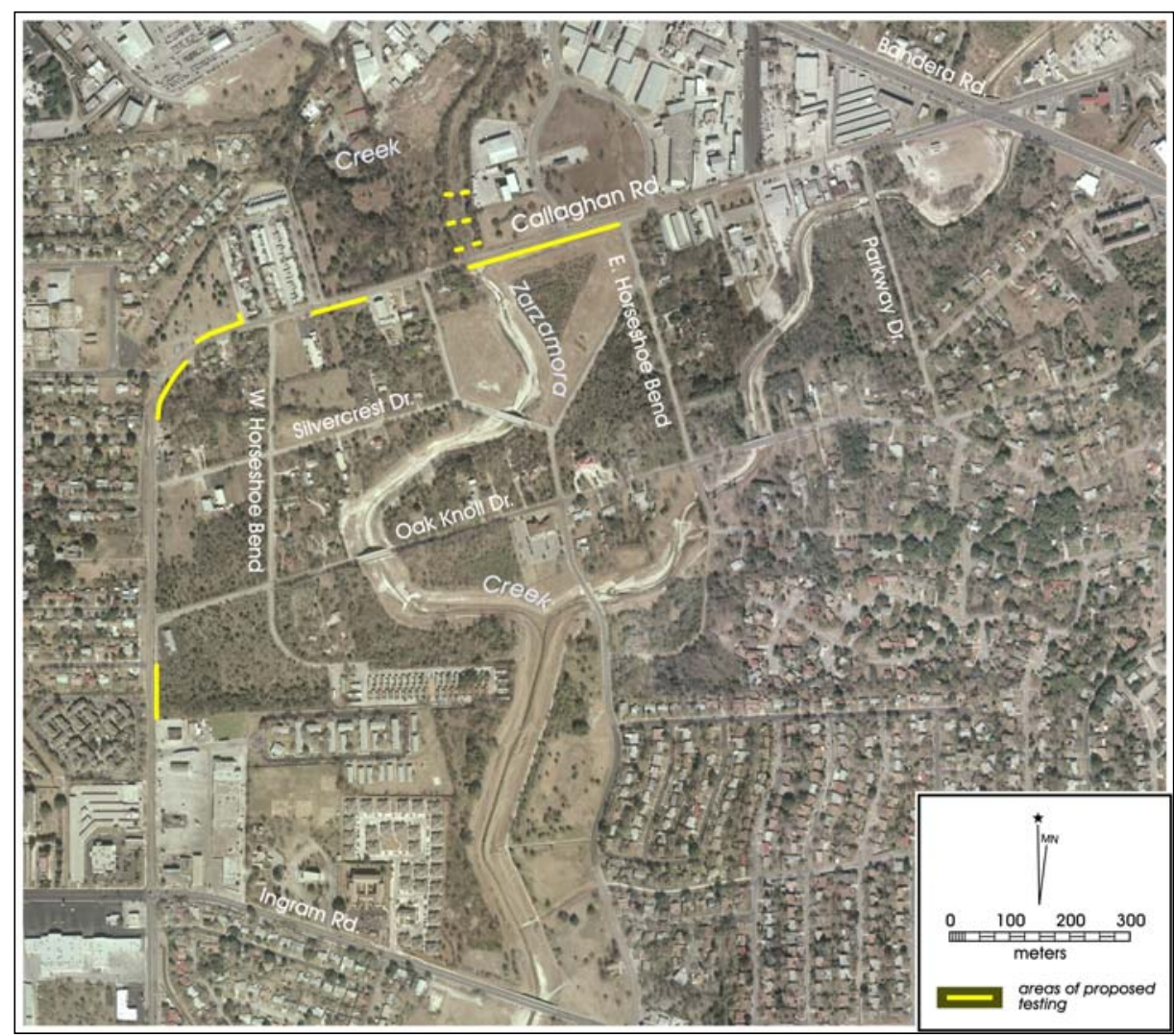

Figure 6. South of Callaghan Road the creek has already been modified from its natural channel. 
West quadrangle, however, the 1973 photo-revision of the 1967 map shows extensive development at the northeast corner of the Callaghan and Ingram Roads intersection. Construction of Callaghan Square at this location has likely obliterated any remnants of the structure noted on the 1942 map.

Of note during the cartographic research was the notation of Zarzamora (also, Salsamora) Creek on each of the maps reviewed. The 1903 map, at 1:62500 scale, notes the stream at approximately the same scale as Culebra and Potranco Creeks and only slightly smaller than Leon Creek. Although an intermittent stream today, it is possible that Zarzamora Creek was at one time a perennial stream. Archaeologically, this is significant in that perennial streams would have provided a reliable source of water for prehistoric inhabitants in the area.

\section{Previous Archaeological Research}

While numerous archaeological investigations have been performed in the urban setting of San Antonio, limited studies have been conducted in the immediate vicinity of the APE. In 1977, the State Department of Highways and Public Transportation (SDHPT; now TxDOT) conducted an archaeological survey along the Loop 410 corridor, north of the proposed project area. No sites were encountered in proximity to the proposed project area. Similarly, in 1989, the SDHPT performed an archaeological survey of Callaghan Road from Ingram Road south to Old Highway 90. No sites were recorded during this survey.

The City of San Antonio Environmental Services Department (ESD) conducted subsurface investigations on Zarzamora Creek immediately south of the Callahan Road. The ESD suspected that this portion of the project area might have been used as a dump for construction refuse. The scope of the investigations was to confirm the presence of a suspected landfill in the area, and characterize the nature of the disturbance and the horizontal and vertical extent of the waste materials placed within the area. The results of these investigations showed that the area to be impacted by the construction activities, measuring approximately .2075-acres immediately south of the Callahan Road at the drainage crossing, has been severely impacted by dumping activities.

\section{Field and Laboratory Methods}

\section{Field Methods}

The Center for Archaeological Research performed an intensive pedestrian survey along 1.5 miles of Callaghan Road between Ingram and Bandera Roads and along $130 \mathrm{~m}$ of Zarzamora Creek north of Callaghan Road that totaled 2.31 acres. Under these project limits, accounting for developed areas where shovel testing could not be performed, CAR proposed to excavate up to six backhoe trenches in each of six defined rechannelization areas, three shovel tests along Zarzamora Creek and six shovel tests in new ROW along . 35 miles in vacant lots on Callaghan Road (Figure 7).

A preliminary reconnaissance of the APE indicated that much of the survey area encompasses commercial and residential properties. Sections of the APE are very narrow and further limit the portions of the ROW available for subsurface testing. During efforts to locate exactly where the proposed channelization impacts were to occur at the six locations on Zarzamora Creek, CAR found the APE to be larger than described in the original research design.

The original scope of work defined six areas targeted for backhoe trenches. We did not excavate in these six specific areas because (1) stakes in the area did not match project plans given to CAR, and (2) after questioning the discrepancy, CAR was informed that the staked area was the correct area of impact. Therefore, CAR proceeded to test the larger area as a single locale rather than six discrete ones. This resulted in the excavation of four backhoe trenches and six shovel tests (rather than the originally proposed three shovel tests) in the staked 2.31 acres (Figure 8). Minimum survey standards for the state of Texas are three shovel tests per acre for project areas totaling 0 to 2 acres and 2 per acre for project areas greater than 3 acres.

The shovel testing entailed manual excavation of small $(\sim 30$ $\mathrm{cm}$ diameter) shovel tests in less developed areas. As per the Minimum Survey Standards of the Texas Historical Commission, six shovel tests were excavated along the approximately .35 miles of roadway where some potential remained for encountering undisturbed cultural materials. Within the areas near Zarzamora Creek, we excavated an additional six shovel tests within the approximately 2.31 acres 


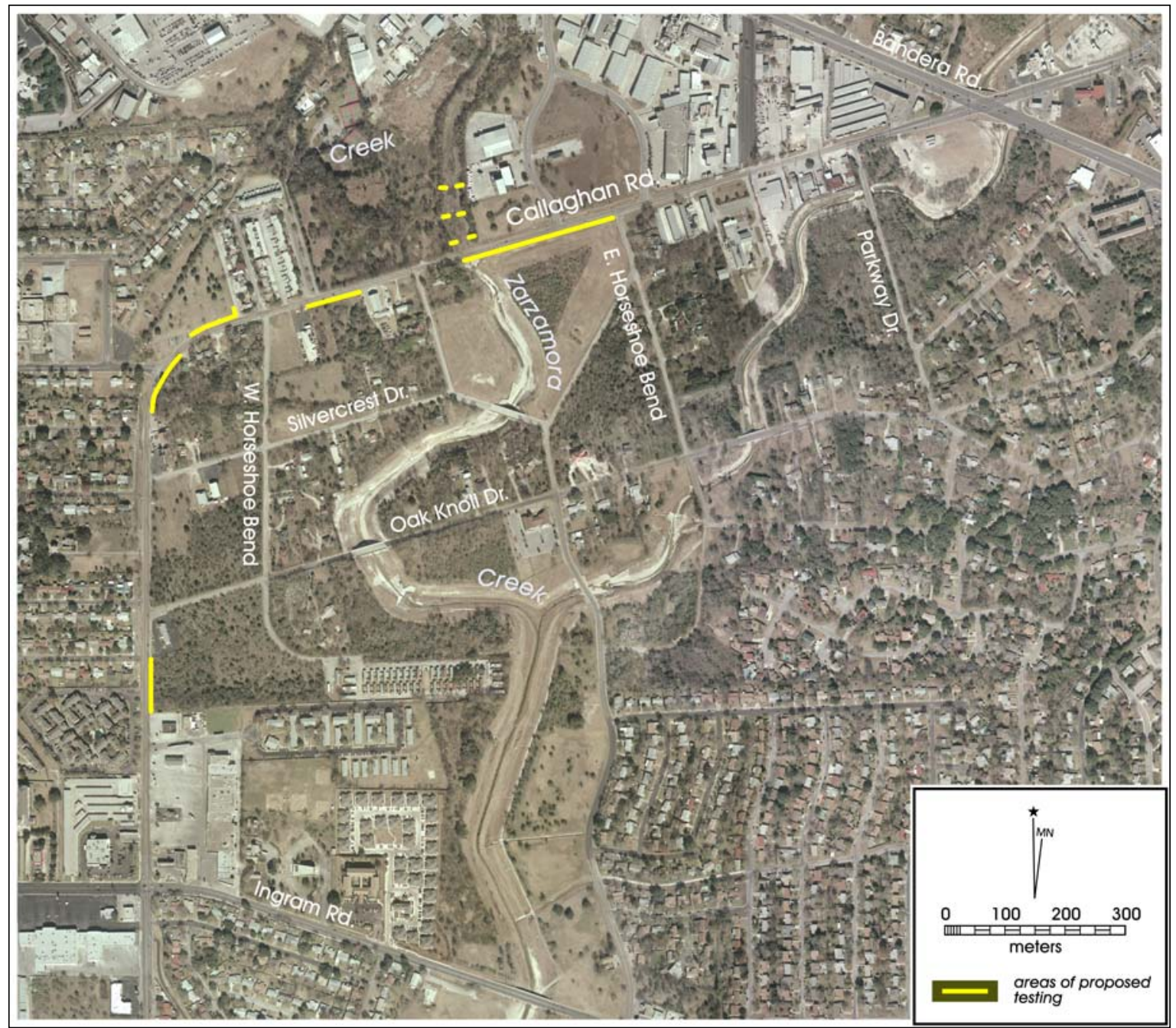

Figure 7. 2006 aerial photograph showing sections along Callaghan proposed for subsurface testing.

there. The shovel tests were excavated in levels not exceeding $10 \mathrm{~cm}$ in thickness. Deposits from these tests were screened through $1 / 4$-in. hardware cloth and observations on the shovel tests were recorded on standardized forms. All shovel test locations were recorded using a Trimble Geo Explorer II Global Positioning System (GPS) unit.

Because the probable depth of deposits in an alluvial setting like Zarzamora Creek would likely preclude examination by typical manual efforts, CAR also conducted deeper mechanical subsurface explorations through backhoe trenching in the areas near the creek. Four backhoe trenches were excavated in areas likely to contain deep deposits subject to subsurface disturbances. These were excavated up to $2.0 \mathrm{~m}(6.5 \mathrm{ft})$ deep. Deeper excavations were not possible for safety reasons. Backhoe trenches also helped to determine the depth of disturbance along Zarzamora Creek and to get to a depth that would reveal archaeological deposits below flood deposits. Each backhoe trench was photographed and one wall drawn in profile detailing stratigraphy and soil characteristics. The locations of backhoe trenches were also recorded with GPS units.

\section{Laboratory and Curation Methods}

No cultural materials were collected during the archeological survey. Field notes, forms, photographs, and drawings were placed in labeled notebooks. All notebooks were stored in acid-free hanging folders. Documents and forms were 


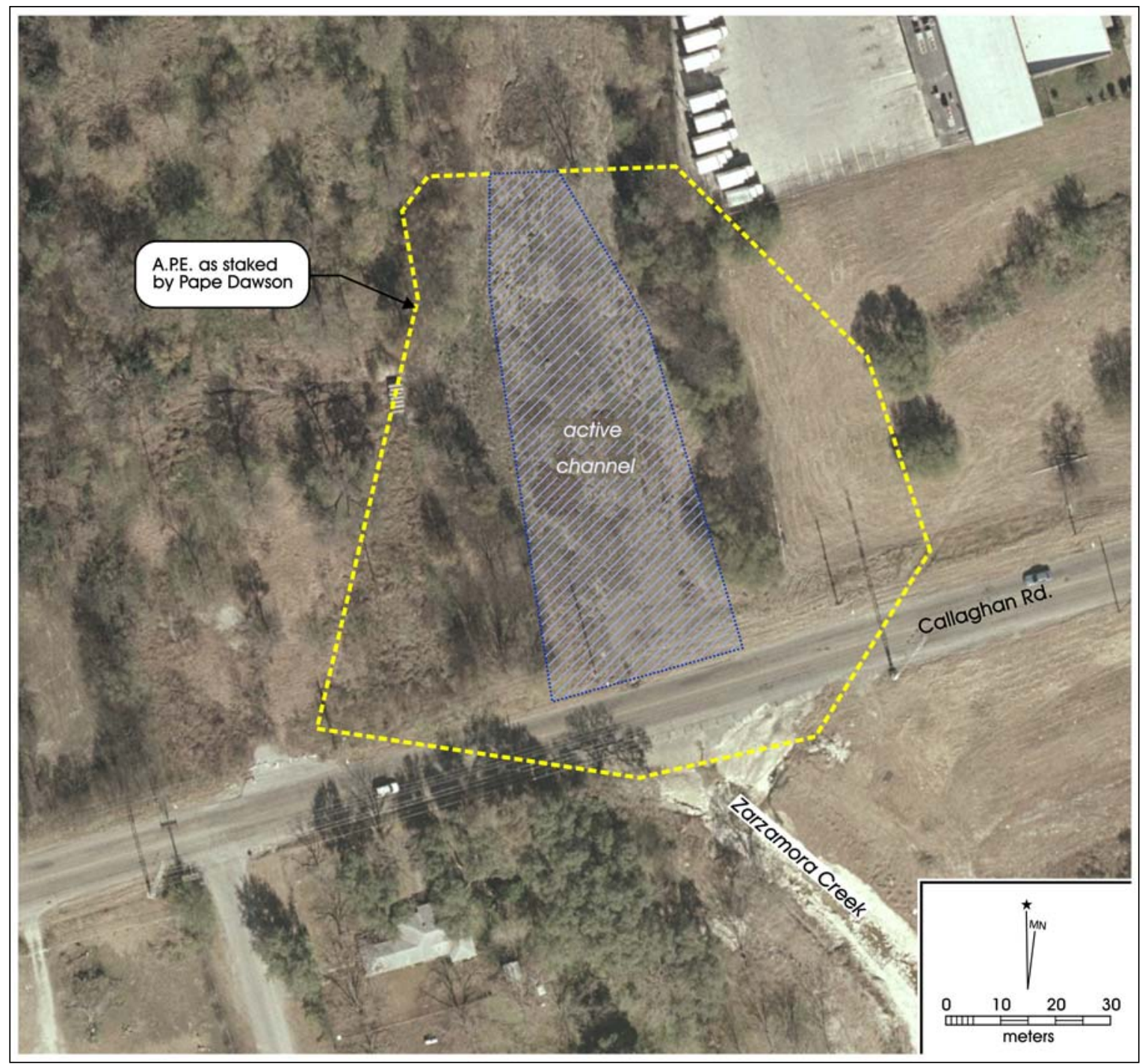

Figure 8. 2006 aerial photograph showing locations of the channel limits as staked by Pape Dawson, Inc. and the originally proposed areas for backhoe trenching.

printed on acid-free paper. A copy of the survey report and all computer disks pertaining to the investigations will be stored in archival boxes and curated with the field notes and documents. Upon completion of the project, all records will be curated at the CAR laboratory and held-in-trust for permanent storage.

\section{Results of Survey}

Shovel tests and backhoe trenches revealed no significant archaeological deposits within the APE. Areas targeted for subsurface testing were in parcels of land that were not paved and therefore conducive to excavation. A discussion of the Zarzamora Creek trenches and shovel tests will follow a description of the testing that occurred along the linear survey of Callaghan Road.

\section{Linear Survey - Callaghan Road}

Subsurface shovel testing occurred in five locales along Callaghan Road (Figure 9). Two shovel tests were excavated between East Horseshoe Bend and Zarzamora Creek and one at each of the following locations: between West Horseshoe Bend and Woodside Drive, between Silvercrest 
Drive and West Horseshoe Bend north of Callaghan, between Silvercrest Drive and West Horseshoe Bend south of Callaghan, and south of Oak Knoll Drive east of Callaghan Road.

CAR personnel found no artifacts within the project area along Callaghan Road. Shovel tests revealed shallow bedrock between 30 and $62 \mathrm{~cm}$ below surface $(\mathrm{cmbs})$ in the western end of the survey area and a construction dump at the eastern end (Figure 10). A large lot between East Horseshoe Bend and Zarzamora Creek proposed for shovel testing was actually quite disturbed upon closer examination. The eastern edge of the lot is paved and the entire lot littered with construction debris (Figure 11). The landform appears artificially raised. We assume that this is part of the construction dump documented previously by the City of San Antonio Environmental Services Department mentioned above. Our assessment, based on the landform, aerial photographs, and the degree of construction material scattered across the lot inside the APE, is that the construction dump spans $43,138 \mathrm{~m}^{2}$ (10.73 acres). All attempts to place shovel tests in this area of the APE failed to encounter intact soil. Attempts to place the shovel tests on the west side of Zarzamora Creek also resulted in excavation of construction material.

Other shovel tests excavated along Callaghan Road were not as disturbed. Shovel Test 9, excavated in a vacant lot between Woodside Drive and Horseshoe Bend West revealed the deepest soil deposits. The soil profile here exposed very loose, friable silty-clay within the upper $30 \mathrm{~cm}$ and very compact silty clay in the lower $30 \mathrm{~cm}$. This shovel test did not contain artifacts. Shovel Tests 10-12, excavated through silty clay to levels of weathered bedrock from 45 to $60 \mathrm{cmbs}$ were also void of artifacts.

\section{Zarzamora Creek Excavations}

Excavations performed at Zarzamora Creek included four backhoe trenches and six shovel tests (Figure 12). The west side of this area is filled by construction dumps as previously

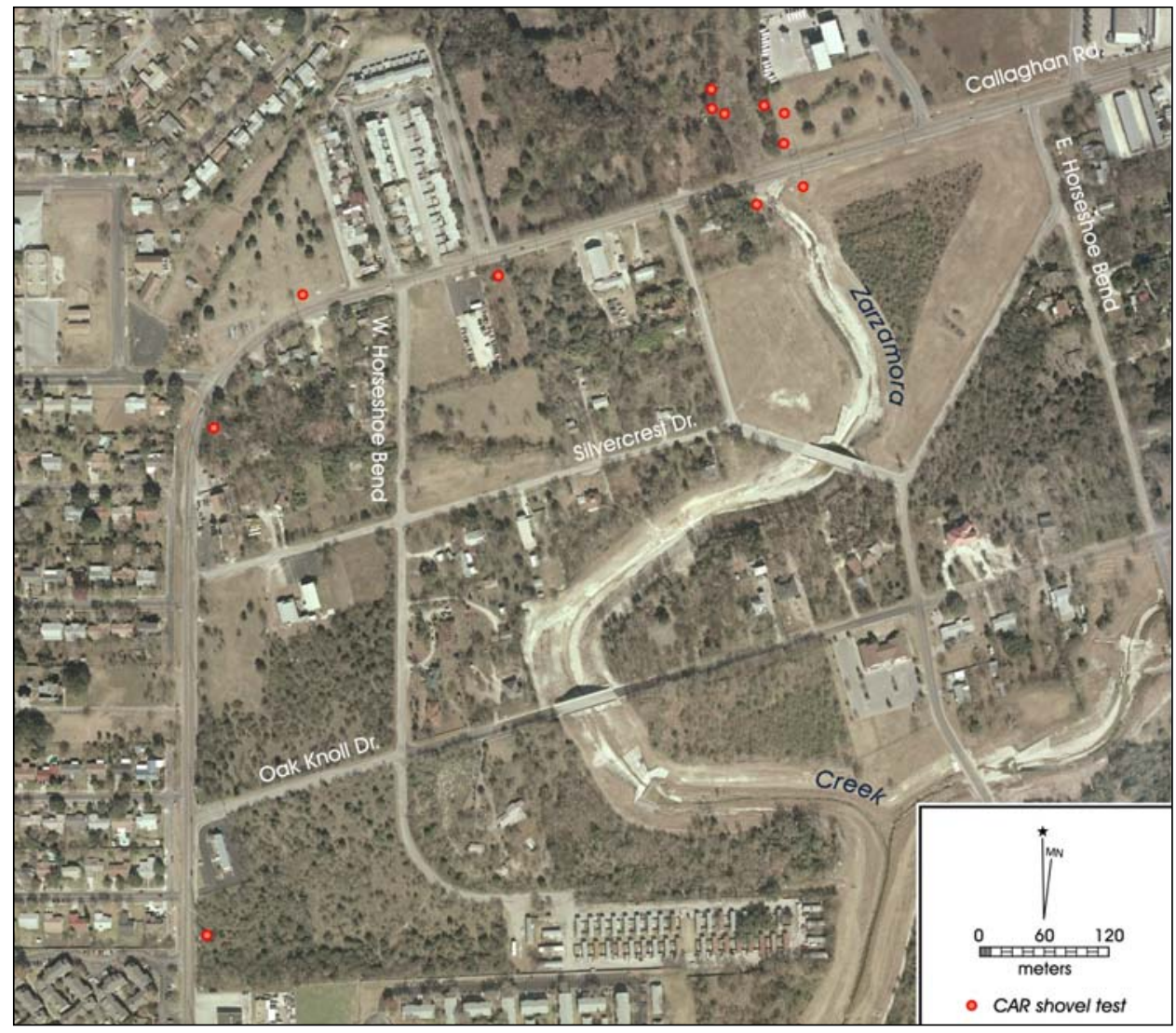

Figure 9. 2006 aerial showing locations of shovel tests along Callaghan Road. 


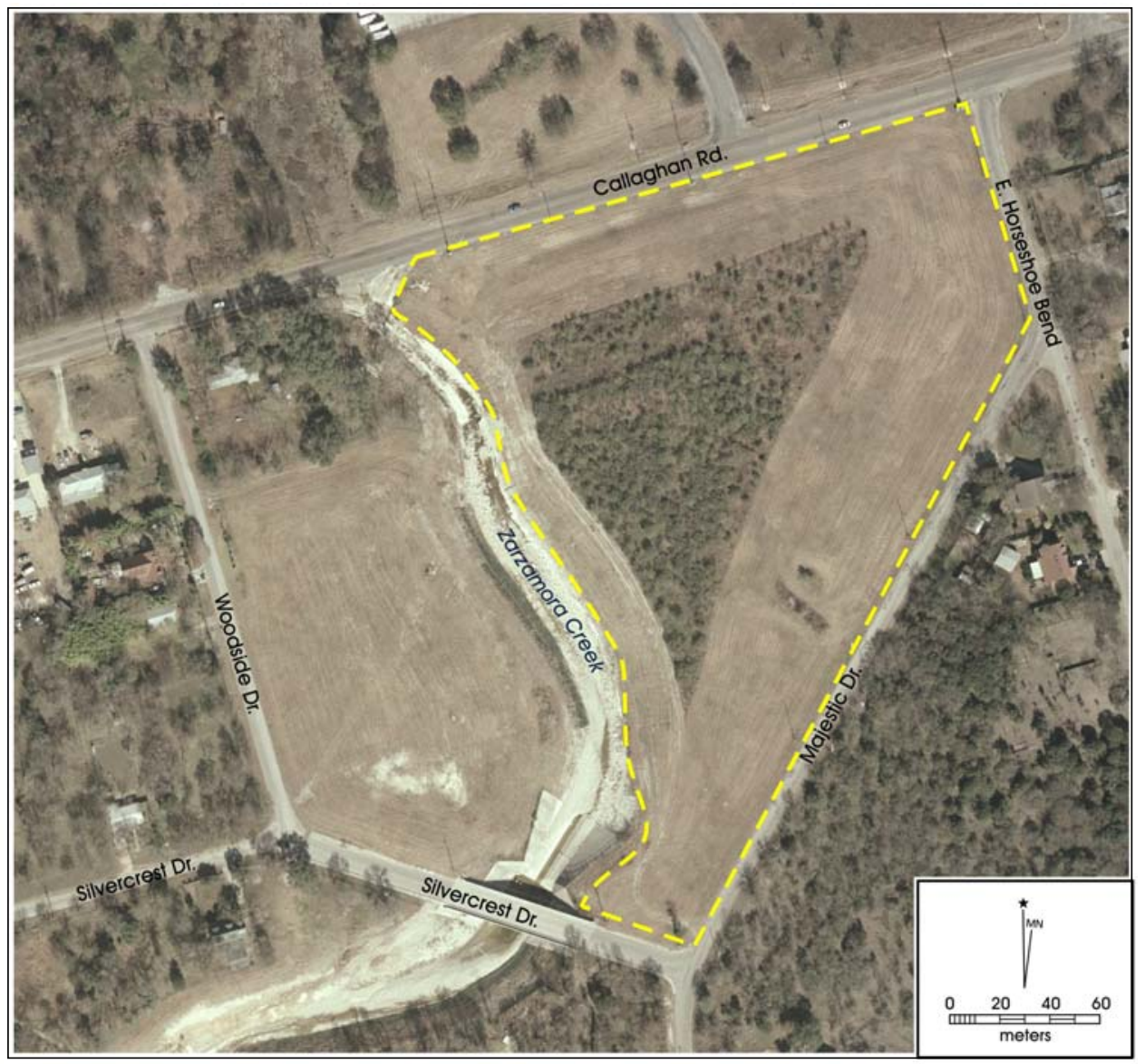

Figure 10. Aerial photograph showing the estimated location of construction dump south of Callaghan between Zarzamora Creek and Horseshoe Bend East.

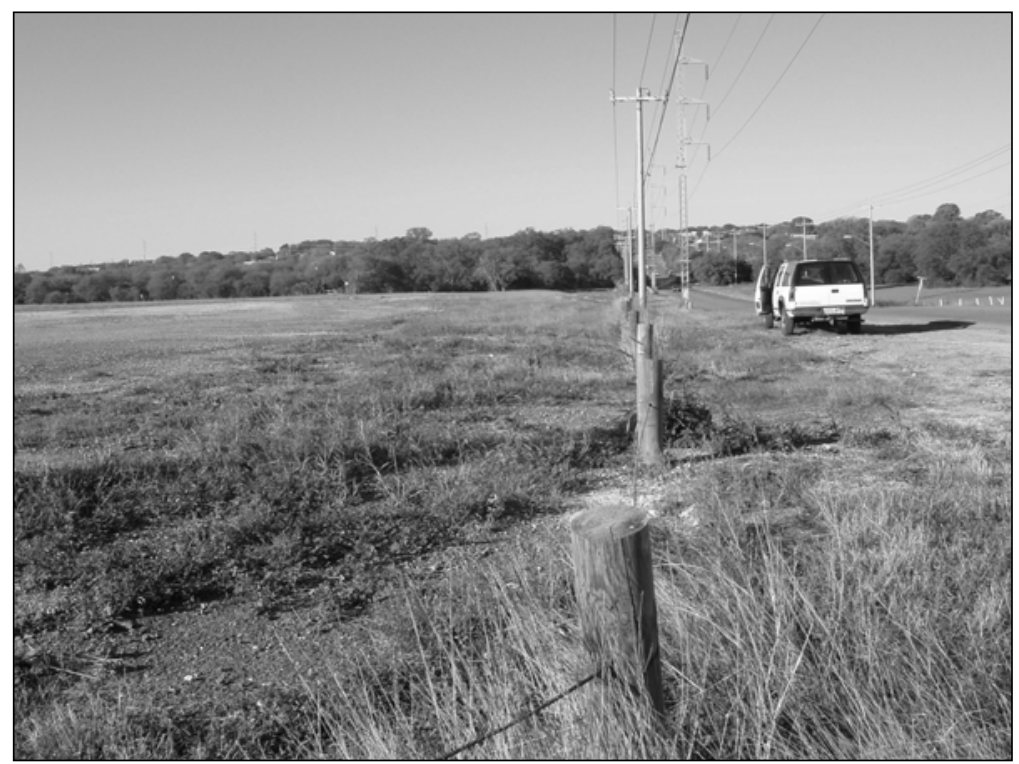

Figure 11. The eastern edge of the lot east of Zarzamora Creek south of Callaghan is paved and the entire lot is littered with construction debris. 


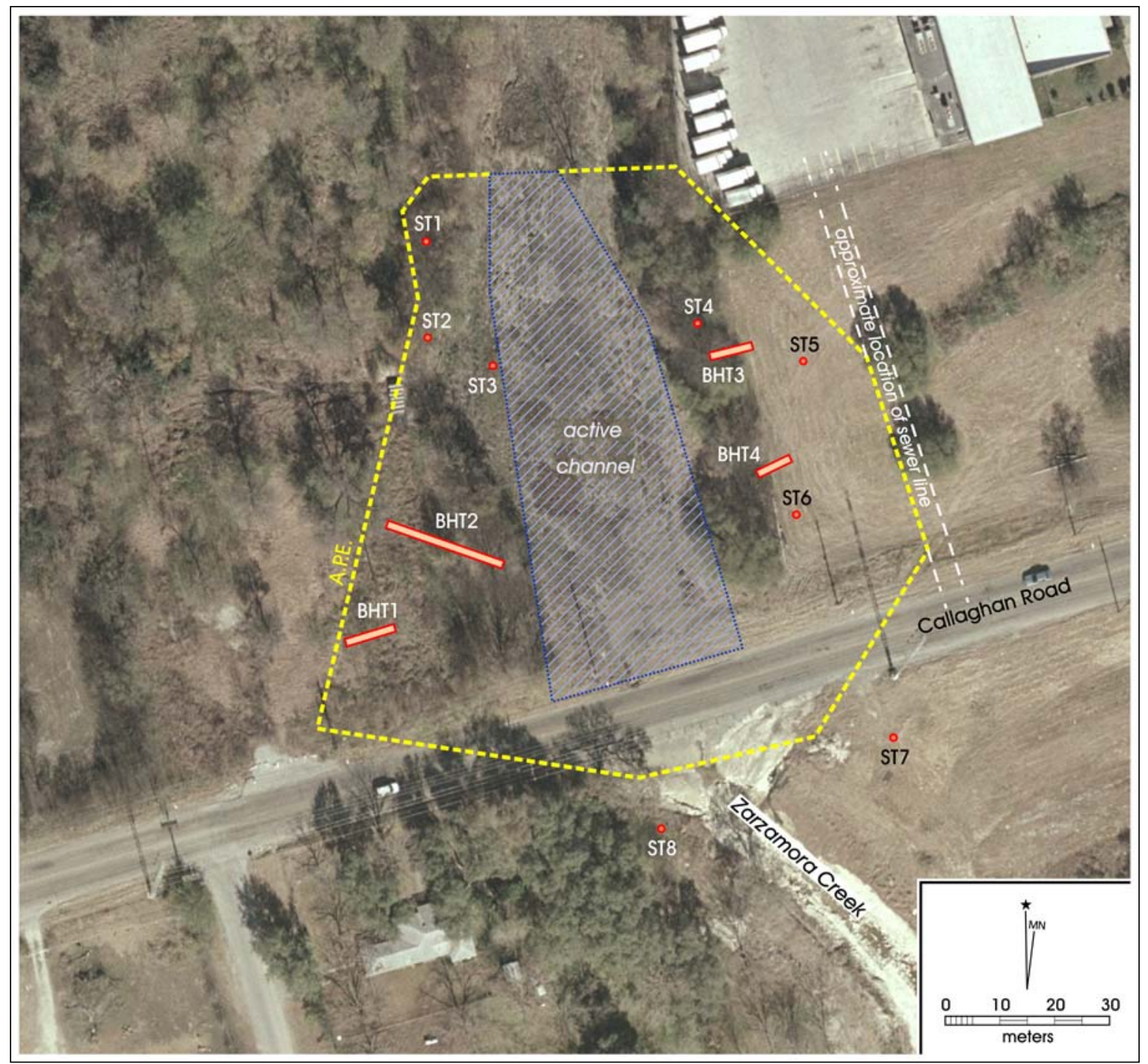

Figure 12. Aerial photograph showing the placement of backhoe trenches and shovel tests near Zarzamora Creek.

mentioned. A sewer main crosses the eastern edge of this area. SAWS failed to locate the sewer line after repeated requests and a site visit with a locator, so placement of Trenches 3 and 4 are according to our judgment of where the line might be based on nearby manholes in Callaghan Road (Figure 12). Excavation of these trenches reached bedrock or stream gravels up to $6 \mathrm{ft}$. deep. A former caretaker visiting the property during our survey reported that for many years during his employment the property owners brought in fill to alleviate flooding on the west side of the creek. Backhoe Trench 2 confirmed this report.
Backhoe Trench 1 was excavated on the west side of the creek on a rise above the current floodplain. Excavation occurred entirely within construction fill and revealed no significant archeological deposits (Figure 13). To determine the extent of this construction fill, we excavated a long trench from closer to the active channel west in an attempt to locate the eastern edge of the dump. Backhoe Trench 2 showed the most informative profile spanning $20 \mathrm{~m}$ long (Figure 14). The center of the trench exposed the following profile (Figure 15). The top $10 \mathrm{~cm}$ of silty loam over $60 \mathrm{~cm}$ of fill and gravels likely brought in by owners. Below the modern fill lies $80 \mathrm{~cm}$ of alluvial clay with creek gravels and pebbles. Creek channel 


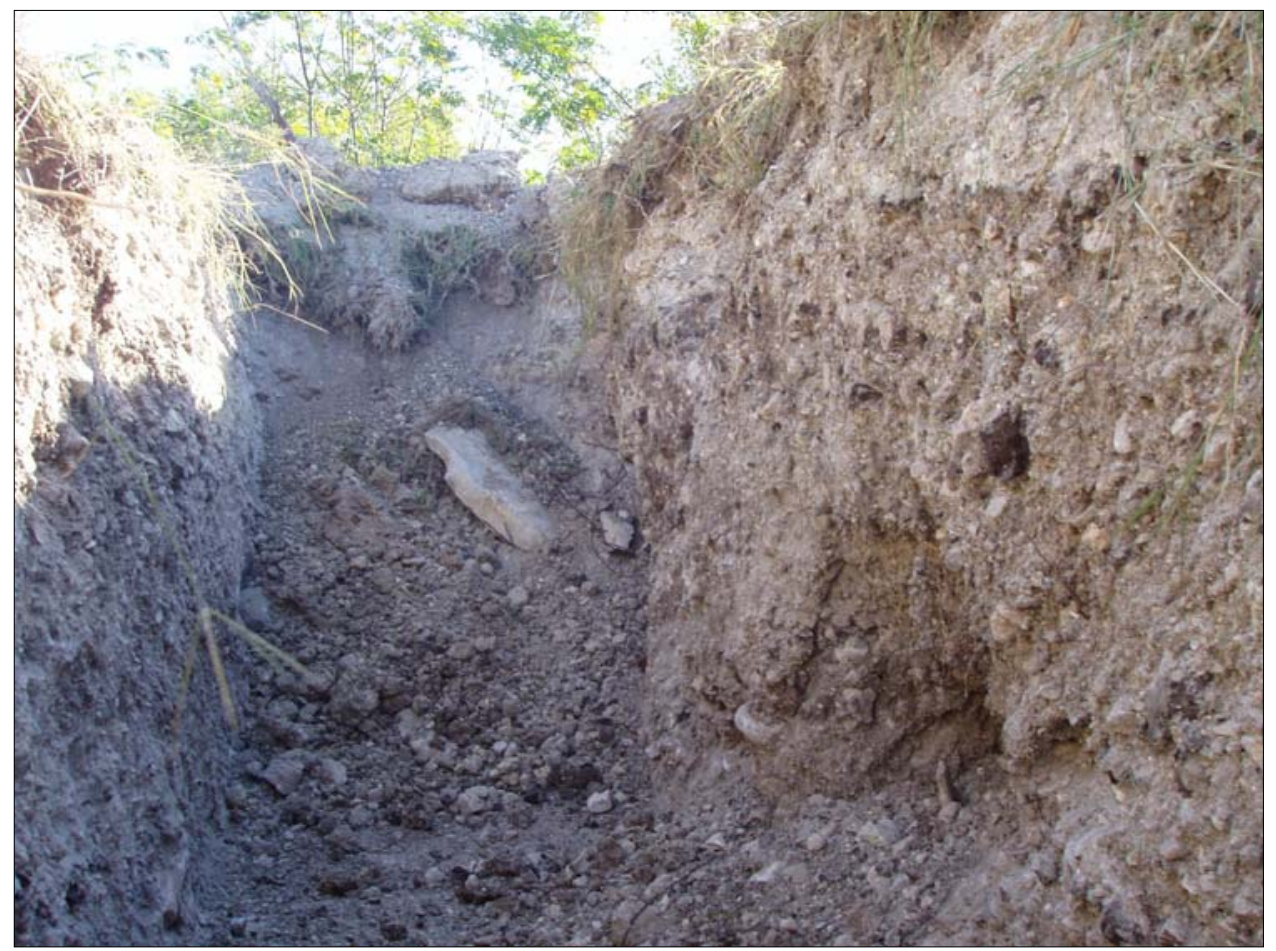

Figure 13. Photograph of Trench 1 excavated entirely in construction fill.

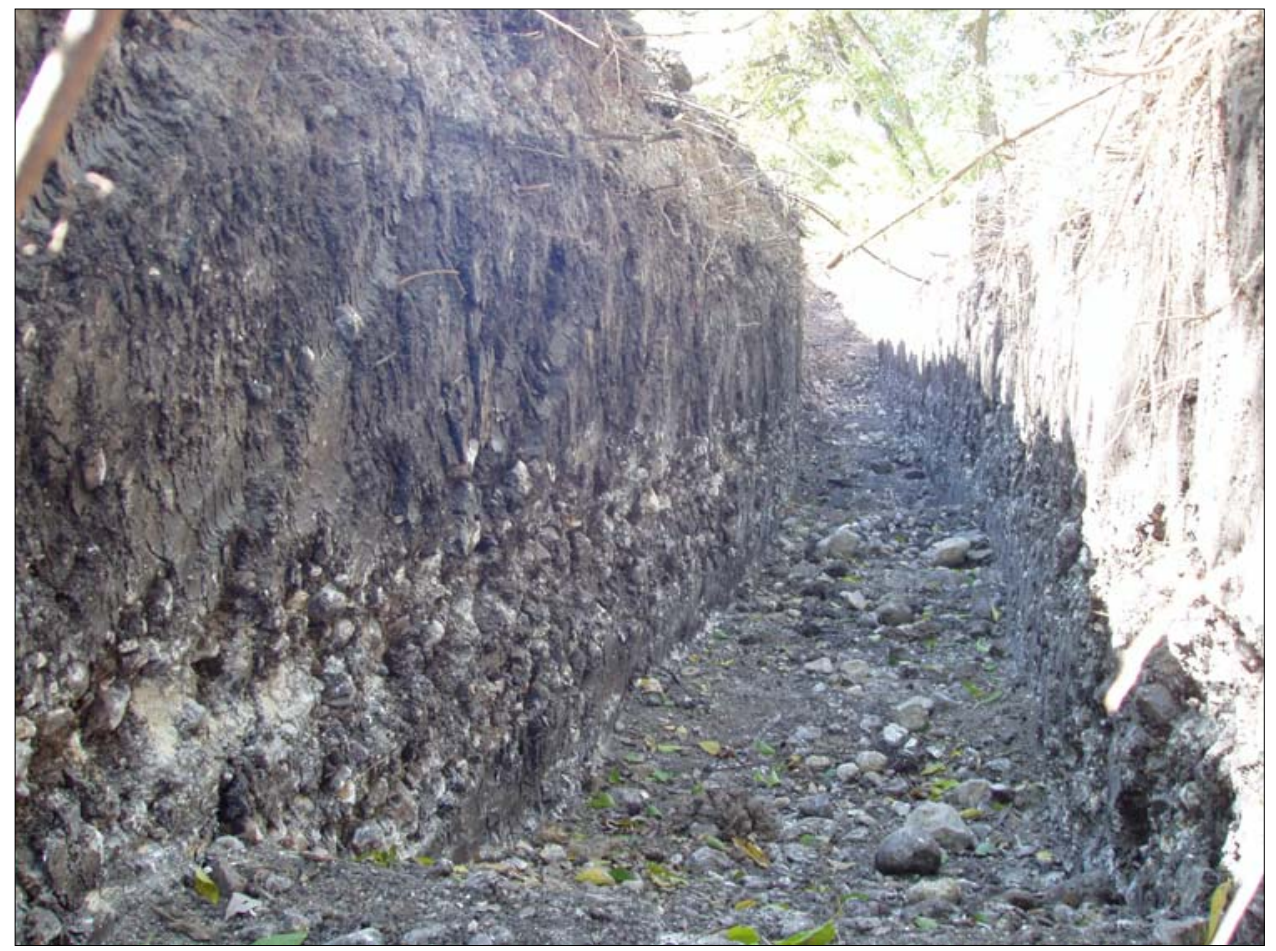

Figure 14. Photograph of Backhoe Trench 2. 


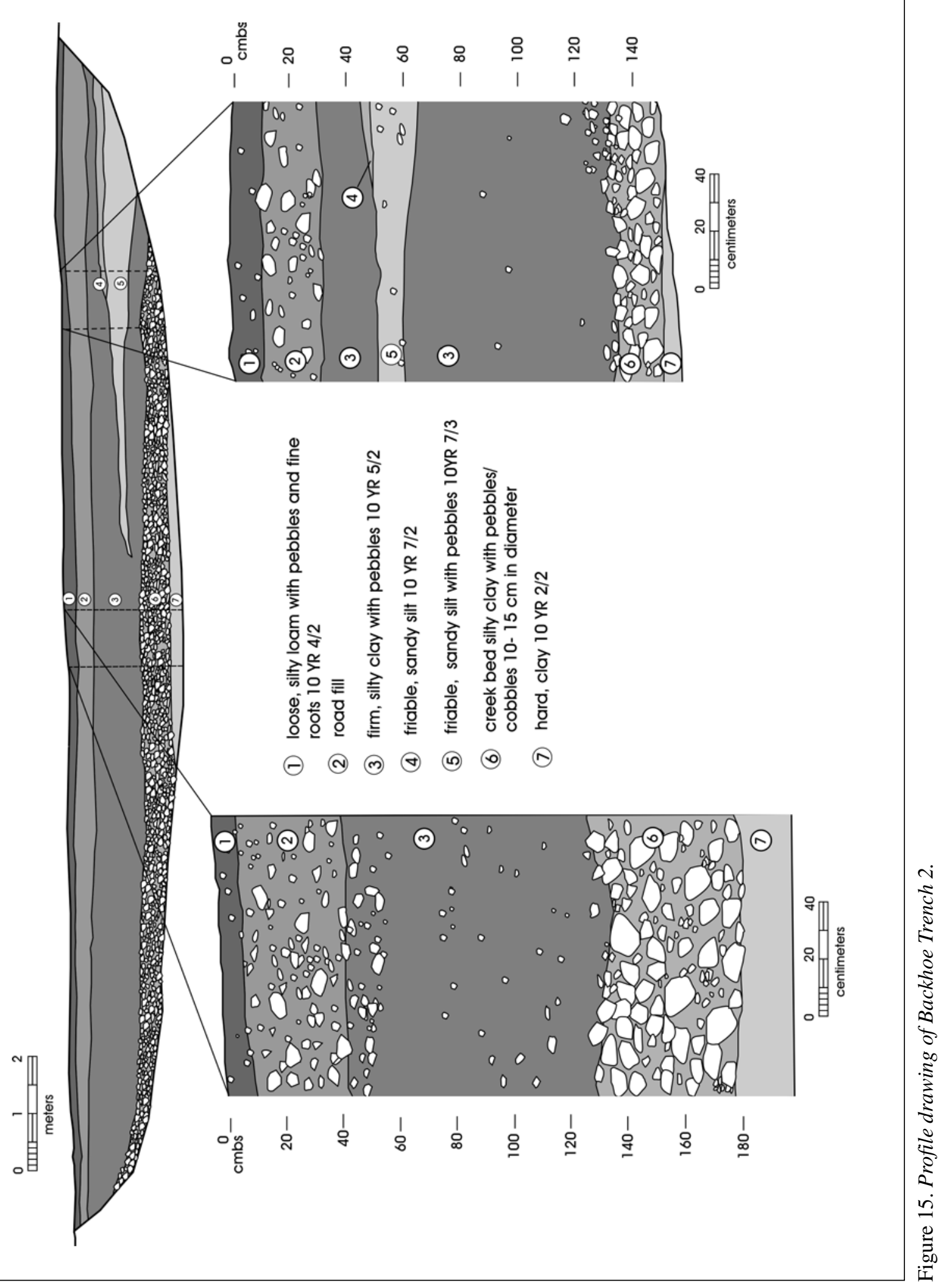


gravels increase at $125-130 \mathrm{cmbs}$ and continue for $50 \mathrm{cmbs}$. At the bottom of the trench lies dark clay at 2.0 meters below surface (mbs).

At the western end of Backhoe Trench 2, a sandy lens was uncovered at $50 \mathrm{cmbs}$. Above this lens, the same modern fill was exposed. The sandy lens and deposits below appear to be alluvial deposits similar to the previous profile with alternating strata of silty clay and creek gravels (Figure 15).

Backhoe Trenches 3 and 4 were placed on the eastern side of the Zarzamora Creek flood zone near the sewer line and the Blue Bell Creameries building. Both trenches exposed silty clays. Backhoe Trench 3 exposed silty clay with some gravel inclusions to $150 \mathrm{cmbs}$ (Figure 16). Backhoe Trench 4 reached decomposing bedrock at $125 \mathrm{cmbs}$ (Figure 17). The upper $25 \mathrm{~cm}$ showed silty clay loam with roots. Beneath this upper stratum lay compact silty clay with sparse, fine roots. One piece of fire-cracked rock observed in the trench wall lay within this silty clay deposit $25 \mathrm{~cm}$ above a stratum of creek gravels. The stratum of creek gravels was approximately $25 \mathrm{~cm}$ thick sitting on weathered bedrock in this exposure. Soils in Backhoe Trenches 3 and 4 appear to be unaltered by fill or construction dumps, though the area has seen disturbance with the installation of a 22 -in. forced sewer line. We made every effort to place backhoe trenches in undisturbed areas of the APE.

Shovel tests around Zarzamora Creek tested areas inaccessible with the backhoe. These included places crossed by fences or near a culvert barrier on a concrete pad (Figure 18). Shovel tests showed disturbed soils with trash up to $40 \mathrm{cmbs}$ on the west side of the creek. Gravels begin to increase at $30-40 \mathrm{cmbs}$ with no other discernable change in soil texture. The upper $20 \mathrm{~cm}$ are soft silty loam and the lower $40 \mathrm{~cm}$ are compact silty clays with pebbles. Burned rock was identified in the $30 \mathrm{~cm}$ of Shovel Test 1 along with recent trash (plastic grocery bags, machine cut nails, concrete).

Shovel tests on the east side of Zarzamora Creek were extremely difficult to excavate due to the amount of rock present. Very compact gravelly silt clay was noted in Shovel Tests 4, 5 and 6. No artifacts were recorded from these tests.

\section{Conclusions and Recommendations}

During November 2006, the Center for Archaeological Research at The University of Texas at San Antonio conducted a linear survey of Callaghan Road between Ingram and Bandera Roads and backhoe trench excavations at Zarzamora Creek in Bexar County, Texas. CAR conducted this work for HNTB Corporation as part of the City of San Antonio's construction plan to widen Callaghan Road and relieve flooding of Zarzamora Creek. The Federal Highways Administration is partially funding this construction; therefore, these archaeological services serve to meet Section 106 requirements of the National Historic Preservation Act.

No known sites were recorded within the APE and no new sites were recorded during the survey. The linear survey included 1.5 miles of new ROW. Shovel testing by hand was only possible in approximately .35 miles of Callaghan Road. The remaining mileage was paved. CAR did not undertake subsurface investigations in commercial developments. Six shovel tests were excavated along Callaghan Road and six shovel tests were excavated near Zarzamora Creek. These were approximately $30 \mathrm{~cm}$ in diameter and reached up to 60 cmbs. Four backhoe trenches were excavated near Zarzamora Creek to look for archaeological deposits buried in deep alluvium beyond the reach of a shovel test. Two were placed on each side of the flood plain and excavated from 1 to 2 mbs. Chipped stone and fire-cracked rock artifacts seen in the backhoe trenches and shovel tests around Zarzamora Creek were either in disturbed soils associated with modern trash and construction materials or resting above alluvial creek gravels and likely out of primary context.

Callaghan Road crosses a busy residential and commercial neighborhood in west San Antonio. Most of the APE has been disturbed by urban development including underground utilities and construction dumps. Six shovel tests along Callaghan Road showed no evidence of cultural materials. Three of the shovel tests encountered bedrock between 45 and $60 \mathrm{cmbs}$. Two of the shovel tests were excavated entirely within construction fill. Only one shovel test was excavated to $60 \mathrm{cmbs}$ in silty clay. 


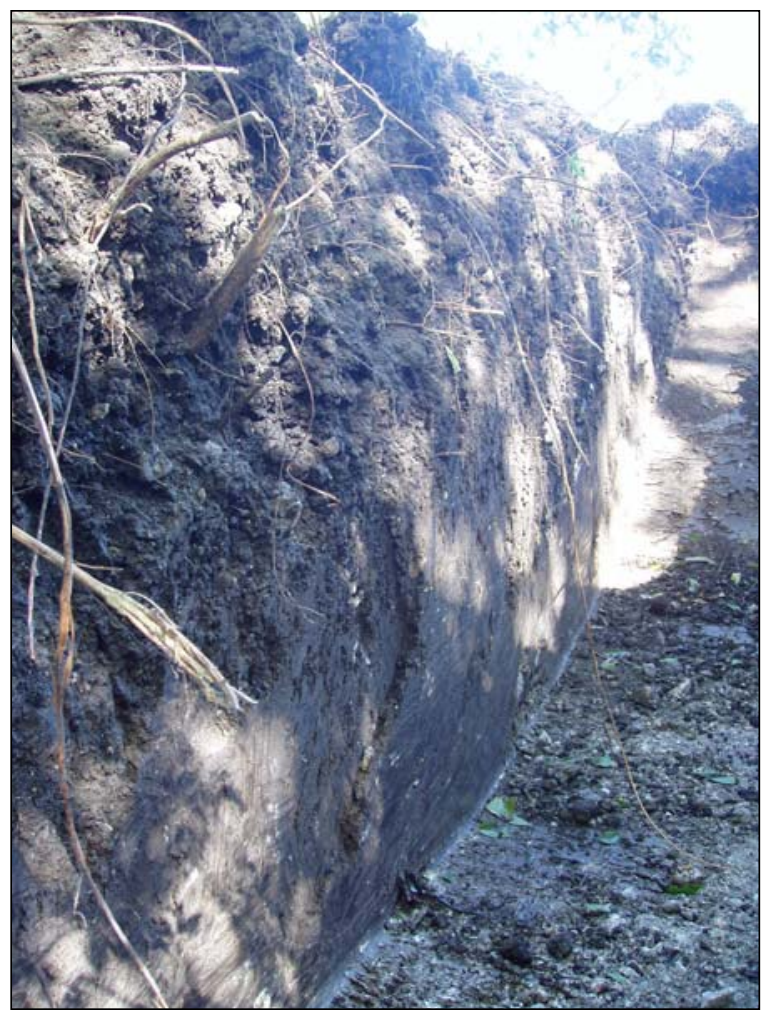

Figure 16. Photograph of Backhoe Trench 3 showing 1.25 meters of silty clay.

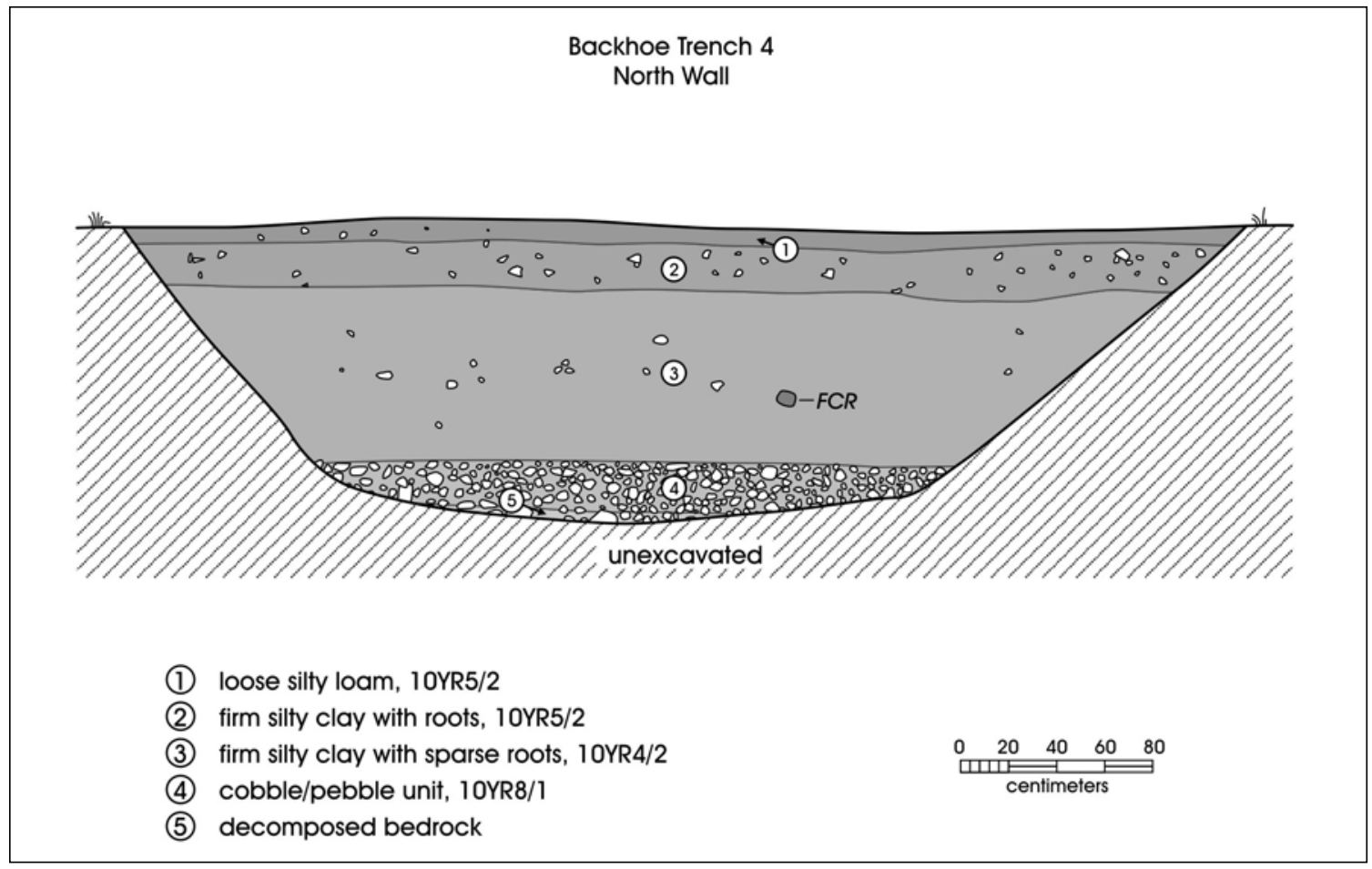

Figure 17. Backhoe Trench 4 was excavated to decomposing bedrock at $125 \mathrm{cmbs}$. 
Alterations to the land surrounding Zarzamora Creek have artificially raised the landform by filling low-lying areas with constructions materials and fill dirt as seen in Backhoe Trenches 1 and 2 and on the surface. Zarzamora Creek channel south of Callaghan Road had already seen dramatic changes. North of Callaghan Road, the creek runs its less engineered course crossing an area overgrown with trees. Landowners have filled the area to alleviate flooding problems on the property. According to a previous caretaker, the culverts that are in place on the property were set up allow creek flow while also serving as part of a fence to keep horses out of the flooded areas of the property. A large sewer line intersects Callaghan Road and crosses the APE near the creek while other utilities lay buried under the ROW parallel to Callaghan Road.

Backhoe trenches along Zarzamora Creek show intact alluvial deposits on the east side of the current flood plain. Here the sewer line has disturbed any deposits that may have been present, but CAR did not see this disturbance in any of the backhoe trenches. West of the floodplain alluvial deposits are intact below artificial fill at $60 \mathrm{cmbs}$. Backhoe Trench 1 was excavated entirely within construction fill.
Backhoe Trench 2 revealed the best profile and encountered alternating strata of silty clay and creek channel gravels up to $2.0 \mathrm{mbs}$. A single chipped stone tool was excavated from the trench and seen in the backdirt. This is a bifacially flaked expedient tool $15 \mathrm{~cm}$ in length with approximately 50 percent cortex remaining. The provenience of this tool is unknown and is the only example of cultural material in the trench. No other cultural items or archaeological deposits were seen in the profile wall. This artifact does not represent a significant archaeological deposit or exhibit any research potential. Fire-cracked rock was recorded from shovel tests on the west side of Zarzamora Creek but these were from the upper levels and associated with modern trash and construction materials. East of the creek, fire-cracked rock was seen above creek gravels in Backhoe Trench 4. This artifact was likely carried in with flood deposits and not in its primary location.

The low density of cultural materials along Zarzamora Creek north of Callaghan Road were found in disturbed deposits or brought in with alluvium. No cultural materials were recorded elsewhere along Callaghan Road. Because we found no evidence of intact cultural deposits within the APE, we recommend construction proceed as planned.

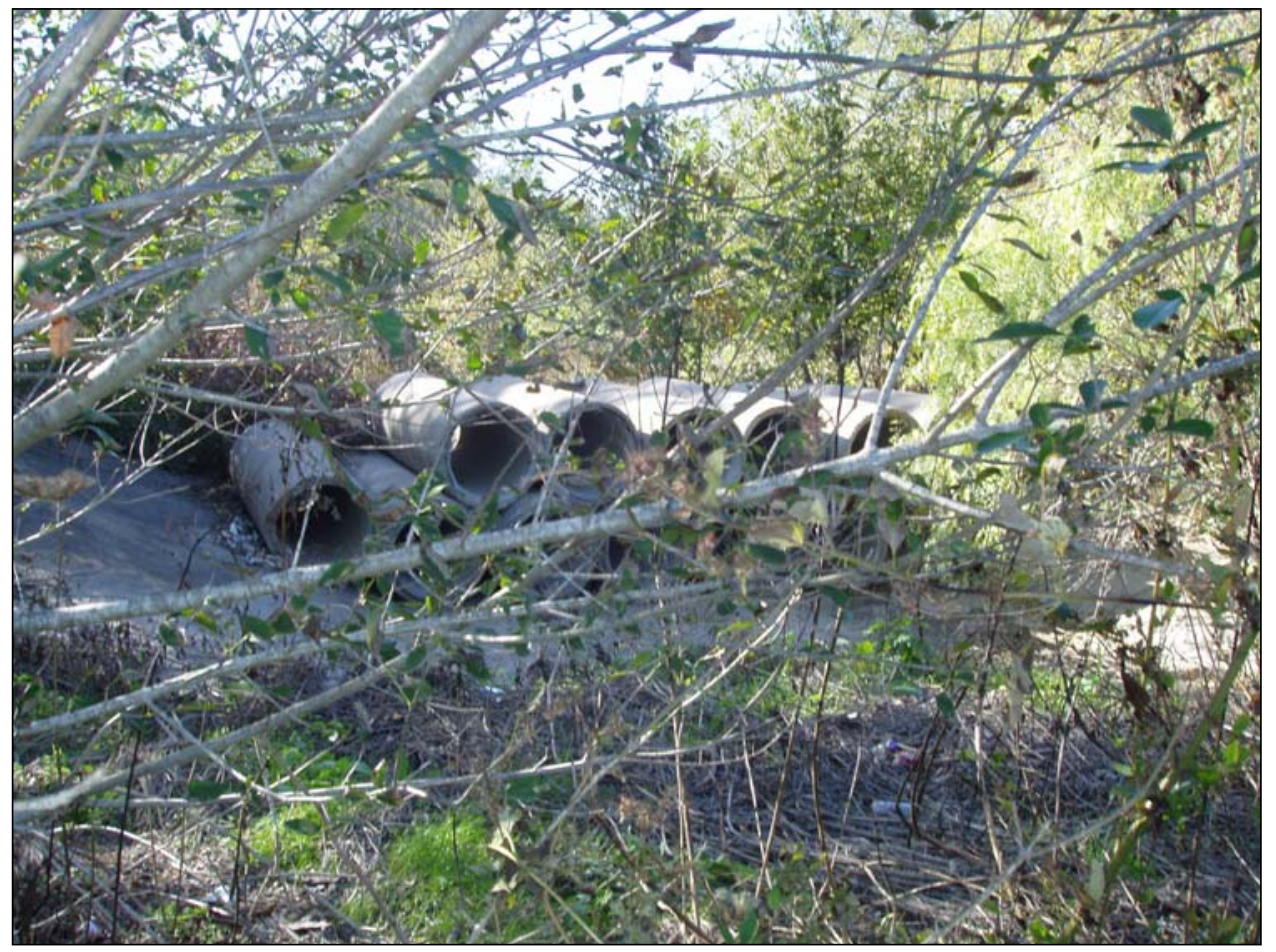

Figure 18. Culverts were stacked to allow floodwaters to drain while also serving to keep horses out of the creek, according to a former horse caretaker on the property. 


\section{References Cited}

Taylor, F. B., R. B. Hailey, and D. L. Richmond

1991 Soil Survey of Bexar County, Texas. U.S. Department of Agriculture Soil Conservation Service. The Soil Conservation Service, Washington, D.C.

Texas Historical Commission (THC)

2006 Texas Archeological Sites Atlas. Electronic database, <http://nueces.thc.state.tx.us/>, accessed November 2006. 